Original Paper http://ajol.info/index.php/ijbcs http://indexmedicus.afro.who.int

\title{
Seasonal distribution of zooplankton in the Aby-Tendo-Ehy lagoons system (Côte d'Ivoire, West Africa)
}

\author{
Ida Attoubé MONNEY ${ }^{1 *}$, Raphael N'doua ETILE ${ }^{1}$, Issa Nahoua OUATTARA ${ }^{1}$ and \\ Tidiani $\mathrm{KONE}^{2}$
}

${ }^{1}$ Laboratoire d'Hydrobiologie, UFR Biosciences, Université Félix Houphouët-Boigny, Abidjan-Cocody, 22 BP 582, Abidjan, Côte d'Ivoire.

${ }^{2}$ UFR Environnement, Université Jean Lorougnon Guede, BP 150 Daloa, Côte d'Ivoire.

${ }^{*}$ Corresponding author; E-mail: monneyattoubeida@yahoo.fr

\section{ACKNOWLEDGMENTS}

The authors wish to express their sincere thanks to PASRES \& RASAPCI for their financial support.

\begin{abstract}
Zooplankton is essential components of aquatic ecosystem where it contributes to transferring energy and organic matter from the primary producers to the higher trophic level taxa. However, changes in some environmental characteristics strongly influence their diversity and abundance. This work aimed at determining the spatial and seasonal distributions of zooplanktonic fauna in relation to some physico-chemical parameters in the Aby-Tendo-Ehy lagoons system. Zooplankton samples were collected monthly from March 2012 to February 2013 in six sampling sites with a cylindro-conical net of $64 \mu \mathrm{m}$ in mesh opening size. Sampling observation showed of 53 taxa including Rotifera, Copepoda and Cladoceran. Rotifera was the most abundant group ( $83 \%$ of total abundance). Overall taxa diversity increased from Aby lagoon $(n=46)$ to Ehy lagoon $(n=$ 50). The total abundance of zooplankton increased from Aby lagoon (mean $=122.8 \mathrm{ind} / \mathrm{l}$ ) to Ehy lagoon (mean $=167.4 \mathrm{ind} / \mathrm{l}$ ). Zooplankton abundance in Tendo and Ehy lagoons were dominated by freshwater taxa (Lecane leontina) while in Aby lagoon this parameter was dominated by brackish water taxa (Brachionus plicatilis). This study revealed that, in Aby lagoon, zooplankton was influenced mainly by salinity, transparency, dissolved oxygen and conductivity. However, in Ehy lagoon zooplankton was influenced by temperature and $\mathrm{pH}$ during the dry season. In Tendo lagoon, main factors are depth during the dry season and $\mathrm{pH}$ and temperature during the rainy season.

(C) 2015 International Formulae Group. All rights reserved.
\end{abstract}

Keywords: Zooplankton, abundance, community distribution, environmental variables, Aby-Tendo-Ehy lagoons, Côte d'Ivoire.

\section{INTRODUCTION}

In Côte d'Ivoire, there are three lagoons systems: Aby-Tendo-Ehy, Ebrié and Grand-Lahou lagoon. Recent studies of zooplankton have been conducted widely in Ebrié (Kouassi et al., 2001, 2006; Pagano et al., 2003; Pagano et al., 2004) and GrandLahou lagoon system (Etilé et al., 2009, 2012, 2015a, 2015b), but not in the Aby-Tendo-Ehy lagoon, the second-largest lagoon system after the Ebrié lagoon system. Zooplanktonic organisms comprise a very important element 
in the food webs of lagoon environments not only as consumers of primary production (Collos et al., 2005), but also as food items for fish species of high commercial value (Brassard, 2009). This importance of zooplankton has been mentioned by several studies (Piasecki et al., 2004; Hoxmeier and Wahl, 2004). The South East Côte d'Ivoire where is located Aby-Tendo-Ehy system, is an important agricultural zone with many industrial palm oil, cocoa, coconuts and rubber tree plantations. These activities can accelerate the natural eutrophication and lead to dystrophic crises due to oxygen depletion (Bartoli et al., 2001) provoking mortalities in the benthic and fish communities, causing sometimes irreversible deterioration of these ecosystems. Located in the South East, the Aby-Tendo-Ehy lagoons system is next to the Tanoé-Ehy Forest, identified as a top priority site for wildlife conservation in West Africa (Zadou et al., 2011). Yet, prior to any bioeconomic models and action plans a good knowledge of the components, structure and functioning mechanisms of the systems are required (Pérez-Ruzafa et al., 2011). To the best of our knowledge, the distribution and monthly densities of zooplankton of this lagoon have not yet been described. This work aimed at determining the spatial and seasonal distributions of zooplanktonic fauna in relation to some physico-chemical parameters in three parts of the Aby-Tendo-Ehy lagoons system.

\section{MATERIALS AND METHODS Study area}

The Aby-Tendo-Ehy lagoons system is located in South east of Côte d'Ivoire $\left(5^{\circ} 05^{\prime}\right.$ $5^{\circ} 22^{\prime} \mathrm{N}, 2^{\circ} 51^{\prime}-3^{\circ} 21^{\prime} \mathrm{W}$ ), and forms a natural border between Côte d'Ivoire and Ghana (Figure 1). It's extends over $30 \mathrm{~km}$ of the coastline and covers an area of $424 \mathrm{~km}^{2}$, with a mean depth of $3.5 \mathrm{~m}$ and width of $5.5 \mathrm{~km}$ (Seu-Anoï et al., 2011). This lagoon system comprises Aby lagoon, Tendo lagoon and Ehy lagoon.

The Aby lagoon covers $305 \mathrm{~km}^{2}$, has a total shoreline of $24.5 \mathrm{~km}$ long, and has 15.5 $\mathrm{km}$ wide. The Tendo lagoon, which is the median part of our study system with a length of $22 \mathrm{~km}$ and a width varying between 1.5 and $3.5 \mathrm{~km}$. The Ehy lagoon is located in the eastern side of the lagoon system and has a surface area of $45 \mathrm{~km}^{2}$ (Seu-Anoï et al., 2011). A total of six sampling sites were selected, distributed along the lagoon system in three areas (Two sites per lagoon) according to different environmental characteristics related to longitudinal salinity range (Figure 1). Ehy lagoon sampling sites had no marine water influences, but were under a contribution of freshwater from the Tanoe Ehy Swamp Forest and Tanoe River. Tendo lagoon sampling sites were near the mouth of Tanoé River. Thus, they receive the bulk of freshwater inflow from Tanoe River. Aby lagoon sampling sites were the most influenced by marine waters. The Aby-Tendo-Ehy lagoons system is situated in a region under the influence of a subequatorial climate characterized by two rainy seasons, a short (October-November) and a long season (May-July); and two dry seasons, a long (December-April) and a short season (August-September).

\section{Measurement of Environmental parameters \\ Water temperature $\left({ }^{\circ} \mathrm{C}\right)$, dissolved oxygen $(\%), \mathrm{pH}$, conductivity $(\mu \mathrm{S} / \mathrm{cm})$ were recorded monthly between 7:00 and 9:00 using a Sper Scientific multiparameter while salinity (ppt) and transparency $(\mathrm{cm})$ were recorded with a Hydrobios refractometer and a Secchi disk (30 cm diameter), respectively. The depth $(\mathrm{cm})$ was recorded at each sampling station.}

\section{Zooplankton sampling}

The zooplankton was monthly collected from March 2012 to February 2013, using a cylindro-conical net $(64 \mu \mathrm{m}$ in mesh opening size, $30 \mathrm{~cm}$ in mouth diameter, and $1 \mathrm{~m}$ in length). The sampling was performed during the day (7:00-9:00 am) and at night (7:00-9:00 pm) by vertical hauls from bottom to the surface to integrate vertical variations, and to minimize effects of diel vertical migrations (Kouassi et al., 2001). Samples were preserved in a mixture of lagoon water and borax-neutralized formalin at a final concentration of $5 \%$. 


\section{Zooplankton identification and counting}

Zooplanktonic organisms were identified according to De Mannuel (2000), Dussart \& Defaye (2001), Sharma (2010), Kotov et al. (2012). The taxa were identified and counted under a microscope. The least abundant taxa were counted on the entire sample, while the most abundant taxa were counted on subsamples made with wide bore piston Eppendorf pipettes of 1 and $5 \mathrm{ml}$. One or several subsamples were examined until numbering a minimum of 100 individual per taxa. Zooplankton densities, expressed as number per liter, were calculated by dividing the number of organisms estimated in each sample by the volume of water filtered (i.e. cylinder defined by the net opening area and station depth).

\section{Statistical analysis}

Species richness and ecological diversity indices (Shannon and Equitability) were used to determine structure and ecological dynamics of zooplankton community. The occurrence percentage (\%OF) was calculated using the following formula: $\% \mathrm{OF}=(\mathrm{Ni} / \mathrm{Nts}) \times 100$, with $\mathrm{Ni}=$ number of samples containing a given taxa I, and Nts = total number of samples collected. The \%OF was used to classify species following Dajoz (2000): \%OF > 50: very frequent taxa; $25<\% \mathrm{OF} \leq 50$ : common taxa; $\% \mathrm{OF} \leq 25$ : rare taxa.

Seasonal variation in zooplankton abundance and environmental variables were evaluated using the Anova test. Environmental influences on zooplankton composition, distribution and abundance were assessed with a ReDundancy Analysis (RDA). Environmental variables and zooplankton data were $\log 10(\mathrm{x}+1)$ transformed prior to analysis. RDA was performed using CANOCO 4.5 (Ter-Braak and Smilauer, 2002) whereas STATISTICA 7.1 computer package was used for the other tests. For this analysis, only taxa whose abundance was $\geq$ $1 \%$ of the total numbers were taken into account. Differences were considered significant when $\mathrm{p}<0.05$.

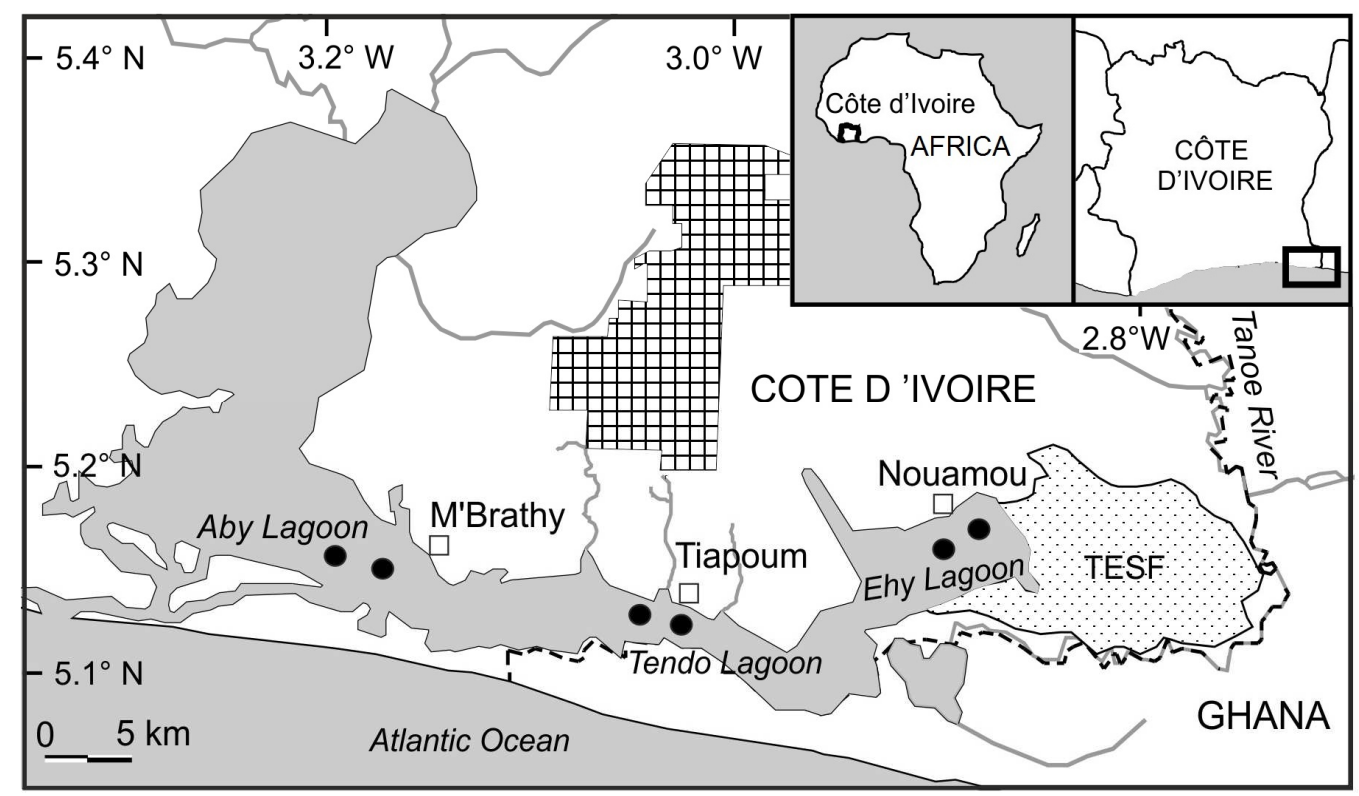

Figure 1: Map showing the localization of the sampling sites $(\bullet)$ in the Aby-Tendo-Ehy lagoons system. 


\section{RESULTS}

Lagoon environmental variables

Overall environmental parameters showed spatial and seasonal variations in Aby-Tendo-Ehy lagoons system (Table 1). Temperature varied between $27.8 \pm 2.5$ and $31.2 \pm 2.8{ }^{\circ} \mathrm{C}$ according to sampling site and season, with maximum and minimum values recorded in Ehy lagoon during the dry and rainy seasons respectively. Salinity values varied little between sites and stations $(<2$ ppt) with hopeless salinity in Tendo and Ehy lagoon. Mean $\mathrm{pH}$, conductivity, transparency and dissolved oxygen rate decreased slightly from Aby lagoon $(6.6 \pm 0.8,473.1 \pm 354.8$ $\mu \mathrm{S} / \mathrm{cm}, 65.6 \pm 13.4 \mathrm{~cm}$ and $76.5 \pm 11.2 \%$ respectively) to Ehy lagoon $(7.1 \pm 0.6,61.2 \pm$ $8.8 \mu \mathrm{S} / \mathrm{cm}, 42.7 \pm 11.7 \mathrm{~cm}$ and $67.7 \pm 17.6 \%$ respectively). In all sampling lagoons, highest $\mathrm{pH}$, conductivity, transparency and dissolved oxygen rate (except in Ehy lagoon) were recorded during the dry season with significant differences between seasons ( $p<$ 0.05) observed in Ehy lagoon for $\mathrm{pH}$, in Tendo for conductivity and in Aby for transparency.

No significant difference $(\mathrm{p}>0.05)$ was observed between seasons for dissolved oxygen rate in all sampling lagoons. Water depth fluctuated slightly between $153.1 \pm 53.4$ $\mathrm{cm}$ (Ehy lagoon) and $455.1 \pm 53.2 \mathrm{~cm}$ (Tendo lagoon).

\section{Zooplankton community and distribution}

A total of 53 taxa of zooplankton belonging to Rotifera (29 taxa), Copepoda (10 taxa), Cladocera (5 taxa) and other zooplankton (9 taxa) were identified in AbyTendo-Ehy lagoons system (Table 2). Zooplankton sampled during this study includes 23 families and 33 genus. The dominant family in species diversity is Brachionidae (8 species) followed by Cyclopidae (4 species) and Filinidae (3 species). Brachionus is the most important Genus, with 5 Species, followed by the genus Filinia (3 species). Among these taxa, 14 were very frequent (occurrence $>50 \%$ ) Lecane leontina, Trichocerca chattoni, Brachionus caudatus, Brachionus calyciflorus, Keratella tropica, Brachionus falcatus, Epiphanes clavulata, Asplanchna girodi, Nauplii, Mesocyclops spp., Thermocyclops sp., Apocyclops panamensis, Harpaticoïds and Moina micrura). Zooplankton diversity varied according to seasons (34-38 taxa in the dry seasons versus 41-45 taxa in the rainy season). According to sampling site, the highest diversity was recorded in Ehy lagoon (50 taxa) versus 46 taxa in Aby lagoon (Table 2).

\section{Community structure and abundance spatio-temporal}

Rotifera was the most abundant group (83\% of the total zooplankton numbers), followed by Copepoda (16\%). Rotifers were dominated by Lecanidae $(67 \%)$ and Brachionidae (24\%). Lecane leontina (67\%) and Brachionus plicatilis (17\%) constituted the bulk of the Rotifera abundance. Copepods comprised $58 \%$ of nauplii and $42 \%$ of copepodid and adult stages. Copepodids and adults included cyclopoïds (74\%), calanoïds (24\%) and Harpaticoïds (2\%). Thermocyclops sp. (16\%) and Apocyclops panamensis (14\%) represented the most abundant taxa among the Copepods. Cladocerans $(<1 \%$ of the total abundance) were dominated by Moina micrura (50\%) and Bosminopsis sp. (24\%).

The zooplankton composition and abundance showed a strong temporal and spatial variation (Figure 2A). The total abundance of zooplankton varied from 23 ind/l (Aby lagoon) to 167 ind/l (Ehy lagoon) (mean: 177 ind/l). Highest total zooplankton abundances were observed during dry season in all lagoons (Figure 2A). But, significant difference between seasons was observed only in Tendo lagoon $(\mathrm{p}<0.05)$. Except Aby lagoon during the rainy season, rotifers constituted the main group in all lagoon (68$91 \%$ ) followed by Copepods (8-34\%). The Figures $2 \mathrm{~A}$ and $\mathrm{B}$ showed the spatial and 
temporal variations of the main group of zooplankton.

Rotifers abundance showed similar variation as total zooplankton abundance, with highest abundances during the dry season for all lagoons (143-203 ind/l) and lowest abundance during the rainy season (34-129 ind/l). In Tendo and Ehy lagoons, Rotifers were dominated by Lecane leontina (57-82\%; 26 to 168 ind/l). In Aby lagoon, Brachionus plicatilis constituted the main taxa during the dry season (90\%; 129 ind/l). On the other hand, during the rainy season, Keratella tropica (38\%; 13 ind/1), Brachionus caudatus and Lecane leontina (18\%; 6 ind/l each one) were the mains species of this group. Brachionus caudatus was obtained with highest abundance in Tendo and Ehy lagoon (14-20 ind/l) whereas highest abundance of Hexarthra intermedia was observed in Tendo lagoon during the dry season (21 ind/l). Total abundance of copepods increased from Ehy lagoon (12 ind/l) to Aby lagoon (40 ind/l) during the rainy season. During the dry season, minimum and maximum of Copepods abundance were recorded in Ehy lagoon (15 ind/l) and Tendo lagoon (47 ind/l) respectively. Except Aby lagoon, the highest abundances of copepods were observed during the dry season (Figure 2). No significant differences were observed between seasons for all lagoons $(\mathrm{p}>0.05)$. Nauplii constituted the dominant taxa for Aby lagoon during dry and rainy seasons.

\section{Diversity evaluation}

During the dry season Shannon diversity index values varied between 0.7 and $1.9 \mathrm{bit} / \mathrm{ind}$ while during the rainy season it ranged between 1.2 and 1.8 bit/ind (Table 2). The lowest and highest values of Shannon diversity index were recorded in Ehy and Tendo lagoons respectively during all seasons. For the equitability index, the maximum and minimum values were recorded during the dry season (0.5 and 0.2). No significant differences were observed in the diversity index (Shannon diversity and equitability index) between seasons for each lagoon (Table 2).

\section{Zooplankton and environmental variables}

According to the ReDundancy Analysis (RDA), the two axes explained $86 \%$ of the observed variance in zooplankton community structure. The first represents more than $70 \%$. These axes were selected for graphical representation (Figure 3). The direct ordination on the dry season distinguished two zones, differentiated mainly by salinity (Figure 3A). The first zones formed by Aby lagoon (salinity $\leq 2.8 \mathrm{ppt}$ ) was positively correlated to the axis I of " the environment" system as opposed to the second zones formed by Tendo and Ehy lagoons (salinity $=0 \mathrm{ppt}$ ). The first zone correlated to salinity, transparency, dissolved oxygen and conductivity, was characterized by Brachionus plicatilis, Nauplii and Keratella tropica.

Whereas, the second group (Tendo and Ehy lagoons) correlated to temperature, $\mathrm{pH}$ and Depth was characterized by Brachionus calyciflorus, Lecane leontina, Asplanchna girodi, Moina micrura, Filinia longiseta, Hexarthra intermedia, Epiphanes clavulata, Brachionus caudatus, Brachionus falcatus, Acartia clausi and Apocyclops panamensis. These two species assemblages could be distinguished within this group according to the second axis. One group of taxa formed by Ehy lagoon was correlated to temperature and pH. This group was characterized by Brachionus calyciflorus and Lecane leontina.

The other group defined by Tendo lagoon was correlated to depth and characterized by Asplanchna girodi, Moina micrura, Filinia longiseta, Hexarthra intermedia, Brachionus falcatus, Apocyclops panamensis and Acartia clausi. During the rainy season (RS), the analysis distinguished also two zones defined mainly by Aby lagoon and Ehy lagoon (Figure 3). The first zone formed by Ehy lagoon was correlated to $\mathrm{pH}$ 
and the second one defined by Aby lagoon to temperature, depth, dissolved oxygen, conductivity, salinity and transparency. The main taxa associated to the first zone were Harpaticoïda, Lecane leontina, Thermocyclops sp., Filinia longiseta, Trichocerca chattoni and Brachionus caudatus. The second zone was mainly characterized by Epiphanes clavulata, Keratella tropica, Nauplii, Filinia opoliensis, Brachionus angularis and Acartia clausi.
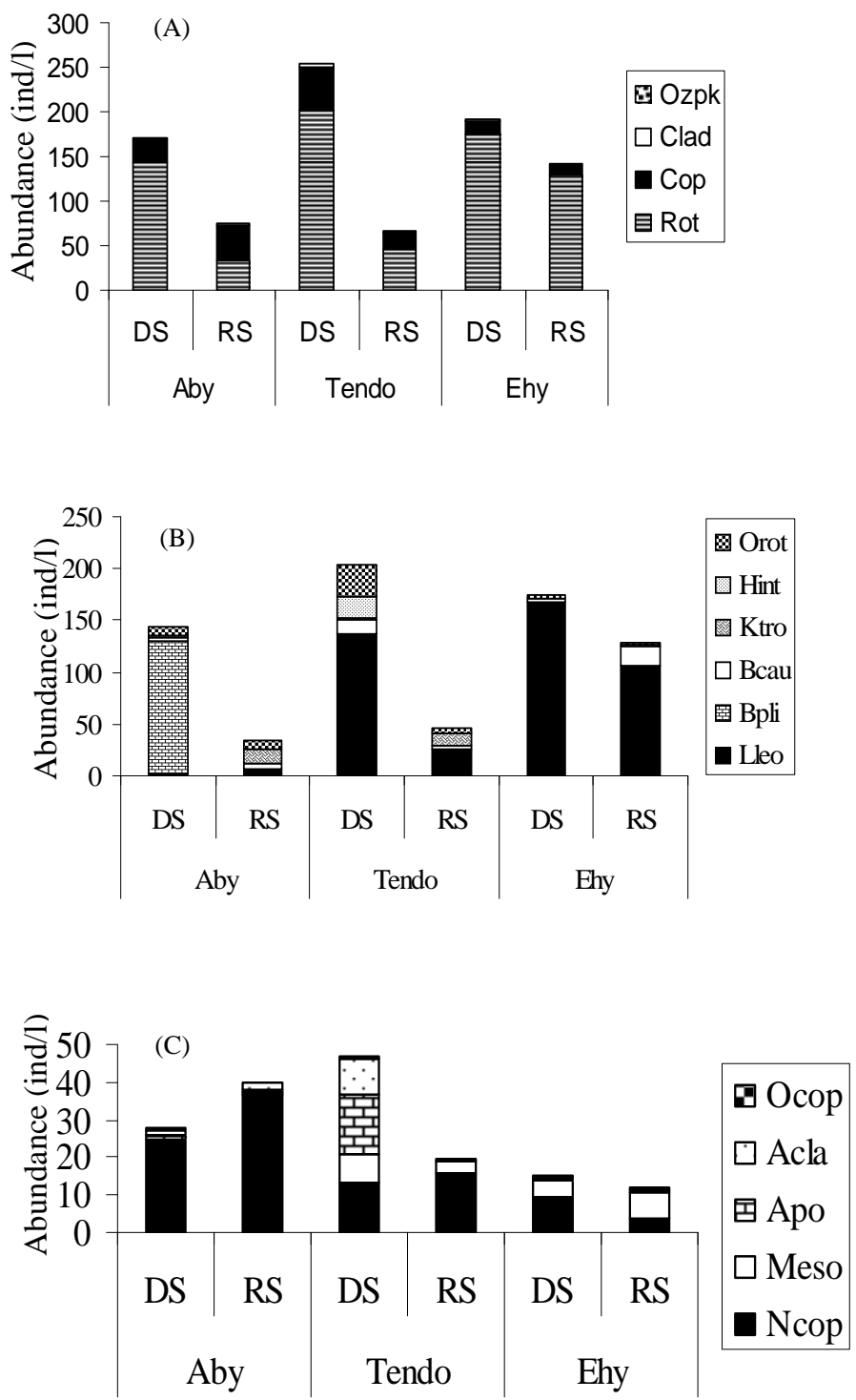

Figure 2: Spatio-temporal variation of the relative abundance of the main zooplankton groups (A), of the main rotifers (B) and copepods taxa (C) in the Aby-Tendo-Ehy lagoon system. (Ozpk: other zooplankton; Clad: Cladocera; Cop: Copepoda; Rot: Rotifera; Orot: other rotifer; Hint: Hexarthra intermedia; Ktro: Keratella tropica; Bcau: Brachionus caudatus; Bpli: Brachionus plicatilis; Lleo: Lecane leontina; Apo: Apocyclops panamensis; Meso: Mesocyclops spp.; Acla: Acartia clausi, Ncop: Copepod nauplii; Ocop: Other copepods). 

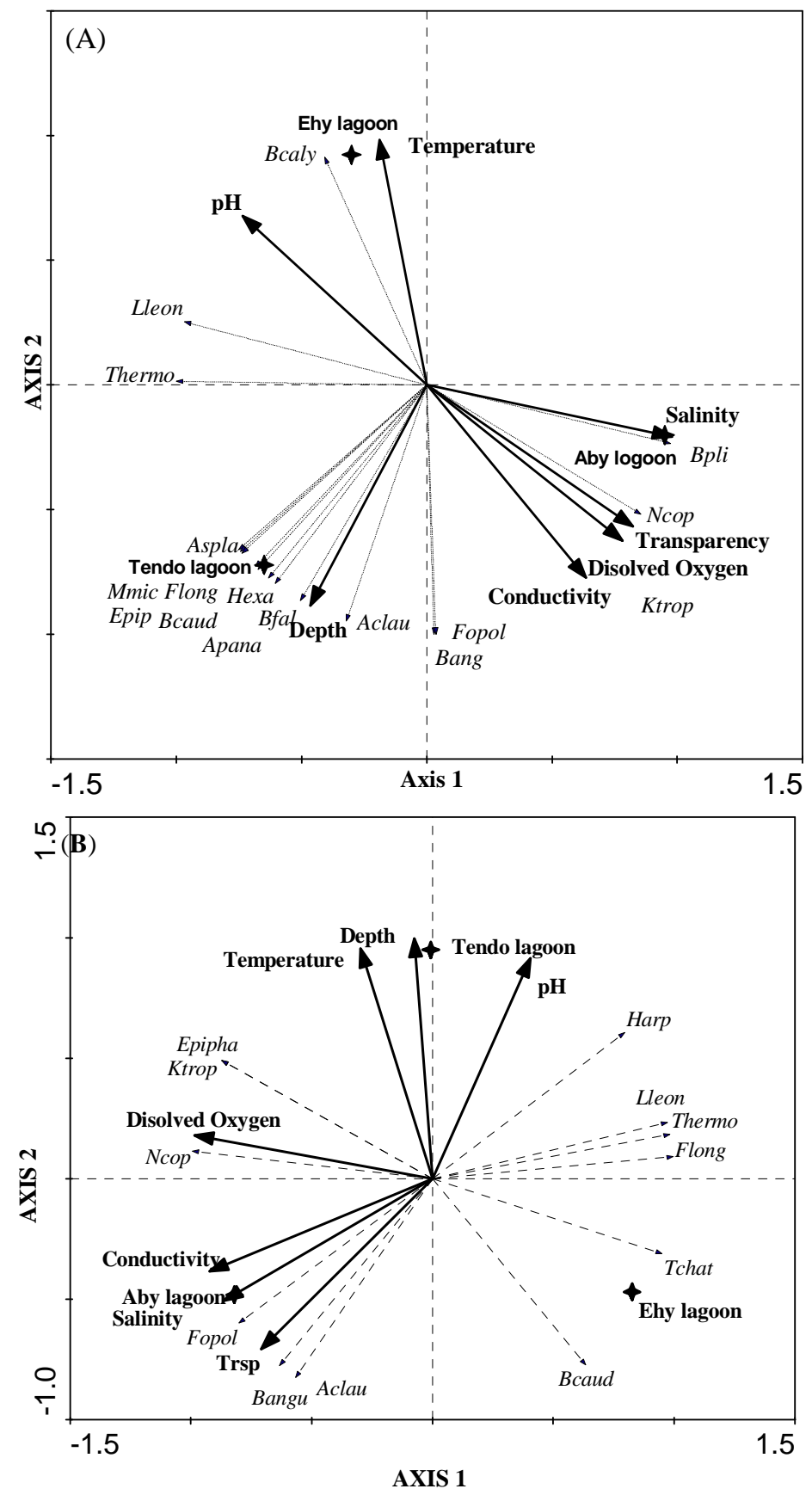

Figure 3: Redundancy analysis ordination diagram applied to environmental variables and zooplankton abundance during the dry season (A) and rainy season (B) in Aby-Tendo-Ehy Lagoons system (Côte d'Ivoire) in Mars 2012 to Februar 2013. ( Bpli: Brachionus plicatilis; Ncop: copepods nauplii; Ktrop: Keratella tropica; Fopol: Filinia opoliensis; Bang: Brachionus angularis; Aclau: Acartia clausi, Bfal: Brachionus falcatus; Apana: Apocyclops panamensis; Bcaud: Brachionus caudatus, Epip: Epiphanies clavulata; Mmic: Moina micrura, Hexa: Hexarthra intermedia, Flong: Filinia longiseta; Aspla: Asplanchna girodi; Thermo: Thermocyclops sp., Lleon: Lecane leontina; Bcaly: Brachionus calyciflorus). 
Table 1: Environmental variables measured during the dry and rainy seasons in the Aby-Tendo-Ehy lagoons system.

\begin{tabular}{llccccccc}
\hline & & \multicolumn{7}{c}{ Environmental variables } \\
\cline { 3 - 9 } Lagoons & Seasons & $\mathbf{T}\left({ }^{\circ} \mathbf{C}\right)$ & DO $(\%)$ & $\mathbf{p H}$ & $\begin{array}{c}\text { Salt } \\
(\mathbf{p p t})\end{array}$ & $\begin{array}{c}\text { Cond } \\
(\boldsymbol{\mu S} / \mathbf{c m})\end{array}$ & Trsp $(\mathbf{c m})$ & Depth $(\mathbf{c m})$ \\
\hline \multirow{3}{*}{ Aby } & DS & $28.9 \pm 1$ & $81.6 \pm 14.1$ & $6.6 \pm 1.2$ & $0.8 \pm 1.2$ & $574.8 \pm 422.6$ & $76.6 \pm 11.9$ & $205.5 \pm 22.2$ \\
& RS & $28.1 \pm 1.7$ & $71.37 \pm 8.3$ & $6.64 \pm 0.5$ & $0.12 \pm 0.4$ & $371.4 \pm 208$ & $54.7 \pm 14.9$ & $207.9 \pm 19.3$ \\
& Mean & $28.5 \pm 1.4$ & $76.5 \pm 11.2$ & $6.6 \pm 0.8$ & $0.4 \pm 0.8$ & $473.1 \pm 354.8$ & $65.6 \pm 13.4$ & $206.7 \pm 20.7$ \\
\hline \multirow{2}{*}{ Tendo } & DS & $28.5 \pm 1.4$ & $73.4 \pm 11.7$ & $7.1 \pm 0.9$ & 0 & $388 \pm 265.2$ & $56 \pm 14,8$ & $358.7 \pm 111.8$ \\
& RS & $28.6 \pm 1.5$ & $70.5 \pm 11.6$ & $6.9 \pm 0.9$ & 0 & $101.1 \pm 30.5$ & $38.2 \pm 13.8$ & $455.1 \pm 53.2$ \\
& Mean & $28.5 \pm 1.5$ & $71.9 \pm 11.7$ & $7 \pm 0.9$ & 0 & $244.5 \pm 146.8$ & $47.11 \pm 14.3$ & $406.9 \pm 82.5$ \\
\hline \multirow{2}{*}{ Ehy } & DS & $31.2 \pm 2.8$ & $66.7 \pm 24.6$ & $7.5 \pm 0.7$ & 0 & $68 \pm 12.4$ & $43 \pm 13.4$ & $153.1 \pm 53.4$ \\
& RS & $27.8 \pm 2.5$ & $68.7 \pm 10.64$ & $6.8 \pm 0.5$ & 0 & $54.5 \pm 5.3$ & $42.5 \pm 9.9$ & $187.6 \pm 64.8$ \\
& Mean & $29.5 \pm 2.7$ & $67.7 \pm 17.6$ & $7.1 \pm 0.6$ & 0 & $61.2 \pm 8.8$ & $42.7 \pm 11.7$ & $170.3 \pm 59.1$ \\
\hline
\end{tabular}

DS: dry season; RS: rainy season; T: water temperature; DO: dissolved oxygen; Salt: Salinity; Cond: conductivity and Trsp: transparency; (Tabulated values are mean \pm standard deviation).

Table 2: Distribution and occurrence of different taxa collected in the Aby-Tendo-Ehy lagoons system.

\begin{tabular}{|c|c|c|c|c|c|c|}
\hline Groups & Famillies & Taxa & Aby & Tendo & Ehy & $\begin{array}{c}\% \\
\text { Occurrence }\end{array}$ \\
\hline \multirow[t]{26}{*}{ Rotifera } & Lecanidae & Lecane leontina & + & + & + & 95 \\
\hline & Colurellidae & Lepadella patella & + & + & + & 10 \\
\hline & Trichocercidae & Trichocerca chattoni & + & + & + & 60 \\
\hline & & Trichocerca sp. & + & + & + & 6 \\
\hline & Filinidae & Filina longiseta & + & + & + & 42 \\
\hline & & Filinia opoliensis & + & + & + & 38 \\
\hline & & Filinia terminalis & + & + & + & 8 \\
\hline & Hexarthridae & Hexarthra intermedia & + & + & + & 23 \\
\hline & Conochiloïdae & Conochilus unicornis & + & + & + & 22 \\
\hline & & Conochiloüdes dossuaris & & & + & 1 \\
\hline & Brachionidae & Brachionus caudatus & + & + & + & 88 \\
\hline & & Brachionus angularis & + & + & + & 40 \\
\hline & & Brachionus calyciflorus & + & + & + & 66 \\
\hline & & Brachionus plicatillis* & + & + & & 22 \\
\hline & & Brachionus falcatus & + & + & + & 80 \\
\hline & & Platyias quadricornis & + & + & + & 2 \\
\hline & & Platyias patulus & + & + & & 4 \\
\hline & & Keratella tropica & + & + & + & 77 \\
\hline & Epiphanidae & Epiphanes clavulata & + & + & + & 73 \\
\hline & Asplanchnidae & Asplanchna girodi & + & + & + & 69 \\
\hline & Synchaetidae & Polyarthra vulgaris & + & + & + & 06 \\
\hline & Euchlanidae & Euchlanis sp. & + & + & + & 12 \\
\hline & & Mytilina mucronata & + & + & + & 13 \\
\hline & Notommatidae & Cephalodella gibba & + & + & + & 40 \\
\hline & & Scaridium sp. & & + & + & 06 \\
\hline & Gastropodidae & Gastropus sp. & + & & & 01 \\
\hline
\end{tabular}




\begin{tabular}{|c|c|c|c|c|c|c|}
\hline & $\begin{array}{l}\text { Philodinidae } \\
\text { Trichotriidae } \\
\text { Undetermined }\end{array}$ & $\begin{array}{l}\text { Philodina sp. } \\
\text { Trichotria sp. } \\
\text { Other Rotifers }\end{array}$ & + & + & $\begin{array}{l}+ \\
+\end{array}$ & $\begin{array}{l}16 \\
01 \\
08\end{array}$ \\
\hline \multirow[t]{10}{*}{ Copepoda } & Families & Nauplii & + & + & + & 96 \\
\hline & Cylopidae & Mesocyclops spp. & + & + & + & 62 \\
\hline & & Tropocyclops confinis & + & + & + & 08 \\
\hline & & Thermocyclops sp. & + & + & + & 92 \\
\hline & & Apocyclops panamensis & + & + & + & 52 \\
\hline & Undetermined & Cyclopoids undetermined & + & & + & 04 \\
\hline & Diaptomidae & Tropodiaptomus sp. & + & + & & 02 \\
\hline & & Pseudodiaptomus hessei* & + & + & + & 03 \\
\hline & Acartiidae & Acartia clausi* & + & + & + & 46 \\
\hline & Undetermined & Harpaticoïds & + & + & + & 63 \\
\hline \multirow[t]{7}{*}{ Cladocera } & Moinidae & Moina micrura & + & + & + & 61 \\
\hline & Daphnidae & Ceriodaphnia affinis & + & + & + & 20 \\
\hline & & Ceriodaphnia cornuta & + & + & + & 25 \\
\hline & Sididae & Diaphanosoma excisum & + & + & + & 28 \\
\hline & Bosminidae & Bosminopsis sp. & + & + & + & 26 \\
\hline & Chydoridae & Alona sp. & + & + & + & 27 \\
\hline & & Chydorus sp. & & + & & $<1$ \\
\hline \multirow[t]{9}{*}{ Other } & Undetermined & Ostracode & + & + & + & 09 \\
\hline & & Arachnids larvae & + & & + & 02 \\
\hline & & Chironomidae larvae & + & + & + & 25 \\
\hline & & Chaoborus larvae & + & + & + & 05 \\
\hline & & Odonate larvae & & & + & $<1$ \\
\hline & & Culex larvae & & & + & $<1$ \\
\hline & & Ephemeroptera larvae & & & + & 01 \\
\hline & & Shellfish larvae & + & & & 03 \\
\hline & & Other insect larvae & + & + & + & 09 \\
\hline Total & 23 & 55 & 46 & 48 & 50 & \\
\hline \multirow{2}{*}{\multicolumn{2}{|c|}{ Taxonomic richness }} & Dry Season & 38 & 43 & 43 & - \\
\hline & & Rainy Season & 41 & 44 & 45 & - \\
\hline \multirow{2}{*}{\multicolumn{2}{|c|}{ Shannon diversity index }} & Dry Season & 1.3 & 1.9 & 0.7 & - \\
\hline & & Rainy Season & 1.8 & 1.8 & 1.3 & - \\
\hline \multirow{2}{*}{\multicolumn{2}{|c|}{ Equitability index }} & Dry Season & 0.4 & 0.5 & 0.2 & - \\
\hline & & Rainy Season & 0.5 & 0.5 & 0.3 & - \\
\hline
\end{tabular}

*: Brackishwater taxa

\section{DISCUSSION}

Fifty-three zooplankton taxa were collected in the Aby-Tendo-Ehy lagoons system throughout the study period. Taxa diversity in this shallow lagoons system is comparable to findings of Miron et al. (2014) in Sontecomapan lagoon (54 taxa). However, taxa diversity in present study is relatively lower than those mentioned by Etilé et al.
(2009) in Grand-Lahou lagoon (Côte d'Ivoire) (65 taxa) and by Badsi et al. (2010) in Masa lagoon in Moroco (61 taxa). The taxa diversity variability could be explained by: (1) high variability of environmental and trophic conditions associated to the shallowness of the lagoon and combined strong influence of freshwater and low influence of marine water, 
(2) localization of sampling site in relation to channel of Assinie.

This study showed that in Aby-TendoEhy lagoons system, the highest diversity was observed among Rotifera, with 29 taxa (52\% of total diversity). This observation was similar to those found in Imboassica lagoon (Brazil) by Branco et al. (2007) (52 species, $56 \%$ of total diversity), in Massa lagoon (Southern Moroco) (35 taxa, 57\% of total diversity) (Badsi et al., 2010). In contrast, in Grand-Lahou (Etilé et al., 2009) and in Ebrié lagoons (Pagano and Saint-Jean, 1994), Copepoda presents highest diversity. Among rotifers, Brachionidae showed the highest diversity (8 species) and the most representative Genera were Brachionus (5 Species) and Filinia (3 species). Brachionus diversity dominance was also reported in other coastal lagoons such as Massa lagoon (10 species) (Badsi et al., 2010) and in some freshwater ecosystems in Côte d'Ivoire (Aka et al., 2000; Ouattara et al., 2007). In Imboassica lagoon (Brazil) where rotifers also presented highest diversity, Lecane constituted the most diversified Genera (13 species) following by Brachionus (7 species) (Branco et al., 2007). High species richness of rotifers in Aby-Tendo-Ehy lagoons system shows a favorable environmental condition for the successive development of several species of this zooplankton group.

According to Badsi et al. (2010), a strong representation of rotifers in aquatic ecosystem can be considered as an indicator of high biological trophic level. Rotifers are able to ingest small particles such as bacteria and organic detritus often abundant in eutrophic environments. In addition, the predominance of rotifer species was attributed to the fact that they are opportunistic, small size, with short life cycles and high tolerance to a variety of environmental factors (Badsi et al., 2010).

Aby-Tendo-Ehy lagoons system zooplankton community reported in this study consisting mainly of fresh and brackish water taxa. Freshwater taxa observed in this survey are common occurrence in several other freshwaters ecosystems in Côte d'Ivoire (Aka et al., 2000; Ouattara et al., 2007) and in the world (Badsi et al., 2010; Sulehria et al., 2012). Brackish zooplankton community found in Aby-Tendo-Ehy lagoon system is similar to those observed in Ebrié Lagoon (Arfi et al., 1987) and in Grand-Lahou lagoon (Etilé et al., 2009). Zooplankton community of Aby-Tendo-Ehy lagoon system is marked by high diversity of freshwater taxa and by the absence of marine taxa in contrast to what is observed in Ebrié (Arfi et al., 1987; Pagano and Saint-Jean, 1994) and in Grand-Lahou lagoon (Etilé et al., 2009). Freshwater zooplankton diversity predominance in AbyTendo-Ehy lagoon system could be explained by the sampling sites localization (far from the channel of Assinie, Figure 1) and by high freshwater inflow from Bia and Tanoe rivers. No proximity influence of sampling site of the Assinie channel and the inflow of Bia and Tanoe rivers confer to this coastal lagoon a freshwater character. Our results underlined numerical dominance of rotifers in AbyTendo-Ehy lagoon system (mean $83 \%$ of total abundance). The quantitative dominance of rotifers has been also reported in Imboassica lagoon (Brazil) (Branco et al., 2007), in Massa lagoon (southern Moroco) (Badsi et al., 2010) and in other tropical water bodies such as Omi river (Nigeria) (Fafioye and Omoyinmi, 2006). In contrast, ours results did not confirm Copepods numerical predominance in coastal lagoons of Côte d'Ivoire as: Aby-Tendo-Ehy lagoon system (92\%; Repelin, 1985), Ebrié lagoon (51-99\%, Repelin, 1985; Arfi et al., 1987; Pagano and Saint-Jean, 1994), GrandLahou lagoon (82-87\%; Repelin, 1985; Etilé et al., 2009). Difference observed could be explained by salinity structuring action on zooplankton composition and distribution in estuary and coastal lagoon (Etilé et al., 2009). Indeed, in Ebrié and Grand-Lahou lagoons, 
the main zooplankton taxa were Oithona brevicornis and Acartia clausi (Arfi et al., 1987; Pagano and Saint-Jean, 1994; Etilé et al., 2009). These species can tolerate salinity ranging respectively from 5 to 30 and 0 to 30 (Arfi et al., 1987). Salinity absence in AbyTendo-Ehy lagoon system has favoured the emergence of freshwater zooplankton taxa such as Lecane leontina, Thermocyclops sp., Apocyclops panamensis, Moina micrura, Bosminopsis sp., etc., in this ecosystem contrary to other lagoon ecosystem in Côte d'Ivoire. Numerical dominance of rotifer in Aby-Tendo-Ehy lagoon system may also be due to several other factors such as fish predation, food (chloropyll-a), dissolved oxygen, water temperature, fluctuations in the water level and low diversity of ecological niche.

Other physical and chemical characteristics of water such as $\mathrm{pH}$, electrical conductivity and total hardness are known to have significant effect on the abundance and composition of rotifers (Sulehria et al., 2012). The most abundant rotifers identified in the present work, Lecane leontina, has a cosmopolitan distribution. Lecane species are typical of littoral regions with aquatic vegetation. Thus, Lecane species such as Lecane elsa, Lecane curvicornis, Lecane leontina, Lecane spp. were collected in the sample from littoral swampy areas (Omondi et al., 2011).

The dominant rotifer taxa, such as Lecane leontina, Brachionus caudatus and Keratella tropica, are common in other eutrophic freshwater (Badsi et al., 2010). Commonly, zooplankton communities of eutrophic freshwater are dominated by smallbodied groups, such as rotifers and Cyclopoid nauplii (Santangelo et al., 2007).

In fact, rotifers and Cyclopoid nauplii comprised almost $70 \%$ of total zooplankton. Copepods and cladocerans were recorded with lowest abundance in this study. Many factors, including fish predation have strong influence on the abundance dynamics of crustacean zooplankton. Fish predation is the most influencing factor controlling the abundance of cladocerans and copepods (EnriquezGarcia et al., 2009). The lowest abundance of copepods and cladocerans was recorded in Ehy and Aby lagoons. In these lagoons, Koffi et al. (2014) revealed the presence of planktivorous fishes. Most fishes feed on cladocerans and copepods since rotifers are no longer energetically profitable. Furthermore, cladocerans and rotifers feed on similar algal types and thus there exists natural competition between these two groups (HurtadoBocanegra et al., 2002). When fish selectively feed on crustaceans, the competitive outcome between rotifers and cladocerans shifts in favour of rotifers and hence they proliferate. In Aby-Tendo-Ehy lagoons, the low zooplankton abundance observed during the rainy season was related to dilution processes.

During the rainy season, the water of the Tanoé River combined to Bia River provoked a complete flush in Tendo lagoon, whereas the Ehy lagoon remained very little influence. The increase in the Copepod densities in Aby lagoon during rainy season may be caused by the contribution of these species transport from Tendo lagoon.

Physical and chemical data analysed in this study showed variations between the lagoons. Canonical correspondence analysis distinguished two zones during the dry season, differentiated mainly by salinity: Aby lagoon $(0<$ salinity $<2.6 \mathrm{ppt})$ on the one hand and Ehy and Tendo lagoons (salinity $=0 \mathrm{ppt}$ ) on the other hand. The Aby lagoon was distinguished by high salinity, transparency and conductivity and few taxa, while Ehy and Tendo lagoons characterized by low transparency and conductivity and hosted more zooplankton taxa. As suggested by the results of the RDA, salinity associated with transparency and conductivity probably drove the differences observed between zooplankton communities during the dry season. 
Under more saline conditions (dry season), zooplankton diversity and richness were also lower. Thus, salinity showed a stronger negative effect on zooplankton diversity and richness as shown by the correlations. Salinity can thus be considered as the main factor of zooplankton community distribution, as previously discussed by Etilé et al. (2009). These authors pointed out that even relatively small increase in salinity have important consequences for zooplankton communities in coastal systems. The dominant taxa in Aby lagoon was, then, the rotifer Brachionus plicatilis, which is common in saline and brackish waters worldwide during the dry season. The role of $\mathrm{pH}$ in structuring the seasonal dynamics of zooplankton clearly appeared in the RDA. Ehy lagoon was characterized by high $\mathrm{pH}$ and two species while Tendo lagoon was distinguished by low $\mathrm{pH}$ and much species (9 species). Thus, $\mathrm{pH}$ was negatively correlated to taxonomic richness or to the abundance of freshwater rotifers.

The sensibility of freshwater rotifers to high $\mathrm{pH}$ values has been evidenced in several studies (Farshad and Venkataramana, 2012). Rotifers were observed to grow when $\mathrm{pH}$ was in the range of $7.1 \pm 0.9$ in Tendo lagoon. Only few studies examined the relationships between $\mathrm{pH}$ and copepod taxa.

\section{Conclusion}

A total of fifty-three (53) taxa were recorded in the Aby-Tendo-Ehy Lagoons system in this study. Our study drawing up a first inventory of the zooplankton of this ecosystem and showed that the Aby-TendoEhy Lagoon's zooplankton was composed mainly by taxa commonly found in freshwater. Zooplankton community is marked by numerical dominance of rotifers ( $83 \%$ of total abundance). This study revealed that, in Aby lagoon zooplankton was influenced mainly by salinity, transparency, dissolved oxygen and conductivity. However, in Ehy lagoon, zooplankton was influenced by temperature and $\mathrm{pH}$ during the dry season. In Tendo lagoon, main factors are depth during the dry season and $\mathrm{pH}$ and temperature during the rainy season.

\section{COMPETING INTERESTS}

The authors declare that they have no competing interests.

\section{AUTHORS' CONTRIBUTIONS}

IAM did the zooplankton organisms sampling, identification and counting, and the manuscript preparation. RNE helped in zooplankton identification and manuscript preparation and revision. INO was the scientific supervisor and also revised the manuscript. TK was the research project supervisor and also revised the manuscript.

\section{ACKNOWLEDGMENTS}

The authors wish to express their sincere thanks to the staff of Hydrobiology Laboratory of Félix Houphoët-Boigny University (Cocody-Abidjan, Côte d'Ivoire) for their help in dada collection (Bamba Mamadou, Aka N'guessan Maryse, Konan Yao Aristide, Simmou Y. Junior and Djirieoulou K. Claver) and helpful revisions of the manuscript. The authors would like to thank two anonymous referees and the Associate Editor for their valuable comments and suggestions on the manuscript.

\section{REFERENCES}

Aka M, Pagano M, Saint-Jean L, Arfi R, Bouvy M, Cecchi P, Corbin D, Thomas S. 2000. Zooplankton variability in 49 shallow tropical reservoirs of Ivory Coast (West Africa). International Review of Hydrobiology, 85: 491-504.

Bartoli M, Nizzolo D, Viaroli P, Turolla E, Castaldelli, FEA Rossi. 2001. Impact of Tapes philippiarum farming on nutrient dynamics and benthic respiration the 
Cacca di Goro, Hydrobiologia, 455: 203-212.

Badsi H, Ali OH, Loudiki M, El Hafa M, Aamari A. 2010. Ecological factors affecting the distribution of zooplankton community in Massa Lagoon (Southern Morocco). African Journal of Environmental Science and Technology, 4(11): 751-762.

Branco CWC, Kozlowsky-Suzuki B, Esteves FA. 2007. Environmental changes and zooplankton temporal and spatial variation in a disturbed brazilian coastal lagoon. Brazilian Journal Biologia, 67(2): 251-262.

Brassard D. 2009. Variabilité à long terme des Cladocères dans des lacs de la forêt boréale soumis à des perturbations naturelles et anthropiques. Mémoire de Maîtrise, Université du Québec (Canada), $42 \mathrm{p}$.

Collos Y, Husseini-Ratrema J, Bec B, Vaquer A, Lam hoai T, Rougier C, Pons V, Souchu P. 2005. Pheopigment dynamics, zooplankton grazing rates and the autumnal ammonium peak in a Mediterranean lagoon. Hydrobiologia, 555(1): 83-93.

Dajoz R. 2000. Précis d'Ecologie (7ème edn). Dunod, Paris ; 615.

De Mannuel J. 2000. The rotifers of Spanish reservoirs: ecological, systematical and zoogeographical remarks. Liinnetica, 19: 91-167.

Dussart, BH, D Defaye. 2001. Introduction to the Copepoda $\left(2^{\text {nd }}\right.$ edn). Guides to the Identification of the Microinvertebrates of the Continental Waters of the World. Backhuys Publishers: Leiden; 1-344.

Enriquez-Garcia C, Nandini S, Sarma SSS. 2009. Seasonal dynamics of zooplankton in Lake Hetzalin, Xochimilco (Mexico City, Mexico). Limnologica, 39: 283-291.

Etilé NR, Kouassi AM, Aka MN, Pagano M, N'douba V, Kouassi NJ. 2009. Spatio- temporal variations of the zooplankton abundance and composition in West African tropical coastal lagoon (GrandLahou, Côte d'Ivoire). Hydrobiologia, 624: 171-189. DOI 10.1007/s10750008-9691-7.

Etilé NR, Aka MN, Kouassi AM, Pagano M, N'douba V, Kouassi NJ. 2012. Spatiotemporal Variations in the Abundance, Biomass, Fecundity, and Production of Oithona brevicornis (Copepoda: Cyclopoida) in a West African Tropical Coastal Lagoon (Grand-Lahou, Côte d'Ivoire). Zoological Studies, 51(5): 627-643.

Etilé NR, Yao SS, Kouassi AM, Aka MN, Pagano M, N' douba V. 2015a. Diel Variation of Zooplankton Community Composition, Abundance and Biomass in a West African Tropical Coastal Lagoon (Grand-Lahou, Côte d'Ivoire). International Journal of Agriculture Innovations and Research, 3(5): 23191473.

Etilé NR, Yao SS, Kouassi AM, Blahoua KK, N' douba V. 2015b. Spatio-temporal Variations of Abundance, Biomass, and Reproductive Parameters of Pseudodiaptomus hessei (Mrazek, 1895) (Copepoda Calanoida) in a West African Coastal Lagoon (Grand-Lahou, Côte d'Ivoire). African Journal of Environmental Science and Technology, 9(8): 690-700. DOI: 10.5897/AJEST2015.1950.

Fafioye OO, Omoyinmi GAK. 2006. The rotifers of Omi River, Ago-iwoye, Nigeria. African Journal Agriculture Resources, 1(5): 18-188.

Farshad H, Venkataramana GV., 2012. Impact of Physico-Chemical Parameters of Water on Zooplankton Diversity in Nanjangud Industrial Area, India. International Research Journal 1(4): 37-42. 
Hoxmeier RJH, Wahl DH. 2004. Growth and survival of larval Walleyes in response to prey availability. Transactions of the American Fisheries Society, 133: 4554.

Hurtado-Bocanegra MD, Nandini S, Sarma SSS. 2002. Combined effects of food level and inoculation density on competition between Brachionus patulus (Rotifera) and the cladocerans Ceriodaphnia dubia and Moina macrocopa. Hydrobiologia, 468, 13-22.

Koffi BK, Aboua BRD, Tidiani K, Bamba M. 2014. Fish distribution in relation to environnemental characteristics in the Aby-Tendo-Ehy lagoon system (Southeastern Côte d'Ivoire). African Journal of Environmental Science and Technology, 8(7): $407-\quad 415$. DOI:10.5897/AJEST2014.1689.

Kotov AA, Jeong HG, Lee W. 2012. Cladocera (Crustacea: Branchiopoda) of the south-east of the Korean Peninsula, with twenty new records for Korea. Zootaxa, 3368: 50-90. ISSN 1175-5334 (online Edition).

Kouassi E, Pagano M, Saint-Jean L, Arfi R, Bouvy M. 2001. Vertical migrations and feeding rhythms of Acartia clausi and Pseudodiaptomus hessei (Copepoda : Calanoida) in a tropical lagoon (Ebrie, Cote d'Ivoire). Estuarine, Coastal and Shelf Science, 52: 715-728. doi:10.1006/ ecss.2001.0769.

Kouassi E, Pagano M, Saint-Jean L, Sorbe JC. 2006. Diel vertical migrations and feeding behavior of the mysid Rhopalophthalmus africana (Crustacea : Mysidacea) in a tropical lagoon (Ebrie, Cote d'Ivoire). Estuarine, Coastal and Shelf Science, 67(3): 355368.

Miron MB, Castellanos-Paez M, GarzaMourino G, Ferrara-Guerrero M, Pagano M. 2014. Spatiotemporal variations of zooplankton community in a shallow tropical brackish lagoon (Sontecomapan, Veracruz, Mexico). Zoological Studies, 53: 59. DOI: 10.1186/s40555-014-0059-6.

Omondi R, Yasiindi AW, Magana A., 2011. Spatial and Temporal Variations of Zooplankton in Relation to Some Environmental Factors in Lake Baringo, Kenya. Egerton Journal of Science and Technology, 11: 29-50.

Onwudinjo CC, Egborge ABM. 1994. Rotifers of Benin River, Nigeria. Hydrobiologia, 272: 87-94.

Ouattara IN, Ouattara A, Kone T, N'douba V, Gourene G. 2007. Distribution du zooplancton le long de deux petits bassins côtiers ouest africains (Bia et Agnébi; Côte d'Ivoire). Agronomie Africaine, 19(2): 197-210.

Pagano M, Kouassi E, Saint-Jean L, Arfi R, Bouvy M. 2003. Feeding of Acartia clausi and Pseudodiaptomus hessei (Copepoda: Calanoida) on natural particles in a tropical lagoon (Ebrie, Cote d'Ivoire). Estuarine Coastal and Shelf Science, 56(3-4): 433-445.

Pérez-Ruzala A, Marco C, Pérez-Ruzala IM. 2011. Mediterranean coastal lagoons in an ecosystem and aquatic resources management context. Physics \& Chemistry of the earth, 36(5-6): 160166.

Piasecki W, Goodwin AE, Eiras JC, Nowak BF. 2004. Importance of Copepoda in freshwater aquaculture. Zoological Studies, 43(2): 193-244.

Repelin R. 1985. Le zooplancton dans le système lagunaire ivoirien. Variations saisonnières et cycles nyctéméraux en lagune Ebrié. Document scientifique, Centre de Recherches Océanologiques, Abidjan, 16 : 1-43.

Santangelo JM, Rocha AM, Bozelli RL, Carneiro LS, Esteves FA.2007. Zooplankton responses to sandbar 
opening in a tropical eutrophic coastal lagoon. Estuarine, Coastal and Shelf Science, 71: 657-668. DOI: 10.106/j.ecss.2006.09.021.

Seu-Anoï NM, Ouattara A, Kone YJ-M, Gourene G. 2011. Seasonal distribution of phytoplankton in the Aby lagoon system, Ivory Coast, West Africa. African Journal of Aquatic Science, 36(3): 1-10.

Sharma S. 2010. Micro-faunal diversity of cladocerans (Crustacea : Branchiopoda : Cladocera) in rice field ecosystems of Meghalaya. Records of Zoological Survey of India: 110 (1): 35-45.

Sulehria AQK, Musthaq R, Ejaz M. 2012. Abundance and composition of Rotifera in a pond near Balloki headworks. The Journal of Animal and Plant Sciences, 22(4): 1065-1069.
Ter-Braak CJF, Smilauer P. 2002. CANOCO reference manual and Canodraw for Windows user's guide: softare for canonical community ordination (version 4.5). Ithaca, New York: Microcomputer Power. DOI: 10151621/030255-35.

Zadou DA, Inza K, Mouroufié VK, Adou Yao CA, Gleanou EK, Kablan YA, Coulibaly D, Ibo JG. 2011. Valeur de la Forêt des Marais Tanoé-Ehy (Sud-Est de la Côte d'Ivoire) pour la conservation: dimension socioanthropologique. Tropical Conservation Science, 4(4): 373-385. 